\title{
PENGARUH BUDAYA SASAK DAN PENGETAHUAN IBU DENGAN STATUS GIZI IBU HAMIL DI WILAYAH KERJA PUSKESMAS LABUAPI LOMBOK BARAT
}

\author{
Disusun oleh : \\ Ns. Dina Fithriana, M.Si.Med.* \\ *Staf Pengajar STIKES Mataram \\ dinafithriana@ymail.com
}

\begin{abstract}
ABSTRAK
Latar Belakang : Kasus gizi saat ini menjadi masalah yang menjadi perhatian indonesia. Gizi kurang dan buruk merupakan masalah yang dapat menimbulkan the lost generation. Kualitas bangsa dimasa depan akan sangat dipengaruhi keadaan atau status gizi pada saat ini, terutama pada balita dan ibu. Akibat gizi buruk dan gizi kurang bagi seseorang mempengaruhi kualitas kehidupan kelak (DepKes, 2009).

Metode : Rencana penelitian yang digunakan yaitu cross sectional dengan cara pengambilan data yang dilakukan dalam waktu yang bersamaan. Populasinya adalah semua ibu hamil trimester II dan III di wilayah Kerja Puskesmas Parampuan Labuapi Lombok Barat. Jenis sampel dalam penelitian ini adalah Nonprobability Sampling dengan menggunakan tekhnik pengambilan sampel yaitu Quota Sampling sebanyak 30 responden. Analisa data dalam penelitian ini yaitu menggunakan uji Chi Square.

Hasil Penelitian : Hasil penelitian ini adalah Tidak ada pengaruh budaya Sasak dengan status gizi ibu hamil di wilayah Kerja Puskesmas Parampuan Labuapi dibuktikan dengan hasil uji statistik Chi Square dengan menggunakan program SPSS versi 20,0 didapatkan hasil p.value sebesar 0.523 dengan taraf signifikans $\alpha<0.05$ sehingga $p$.value $>\alpha$. Tidak ada pengaruh pengetahuan ibu dengan status gizi ibu hamil di wilayah Kerja Puskesmas Parampuan Labuapi dibuktikan dengan hasil uji Chi Square yang dilakukan didapatkan nilai $p=0.427$ dan taraf kesalahan 0,05. p.value $<\alpha$.

Kesimpulan : Kesimpulan dari penelitian ini adalah diharapkan kepada ibu hamil untuk meningkat asupan nutrisi supaya status gizinya lebih baik dan terpenuhi untuk mencapai kesehatan yang optimal.
\end{abstract}

Kata kunci : budaya Sasak, pengetahuan, status gizi

\section{PENDAHULUAN}

Kasus gizi buruk saat ini menjadi masalah yang menjadi perhatian indonesia. Gizi kurang dan buruk merupakan masalah yang perlu mendapat perhatian, karena dapat menimbulkan the lost generation. Kualitas bangsa dimasa depan akan sangat dipengaruhi keadaan atau status gizi pada saat ini, terutama pada balita dan ibu. Akibat gizi buruk dan gizi kurang bagi seseorang mempengaruhi kualitas kehidupan kelak (Depkes, 2009).

Status gizi ibu sebelum dan selama hamil dapat mempengaruhi pertumbuhan janin yang sedang dikandung bila status gizi ibu normal pada masa sebelum dan selama hamil kemungkinan besar akan melahirkan bayi yang sehat, cukup bulan dengan berat badan normal (Lubis, 2007). Gizi ibu yang buruk sebelum kehamilan maupun sedang hamil lebih 
sering menghasilkan bayi BBLR atau lahir mati dan menyebabkan cacat bawaan (Kusumawati, 2007). Zat besi sangat dibutuhkan oleh ibu hamil untuk mencegah terjadinya anemia dan menjaga pertumbuhan janin secara optimal. Kementerian Kesehatan menganjurkan agar ibu hamil mengonsumsi paling sedikit 90 pil zat besi selama kehamilannya (Depkes RI, 2011).

Status gizi pada ibu hamil dipengaruhi oleh banyak faktor seperti Kondisi kesehatan ibu hamil, pendidikan atau pengetahuan, faktor ekonomi, sosial budaya, termasuk dengan faktor-faktor yang berkaitan dengan kebiasaan dan kesukaan yang sering diterapkan oleh ibu hamil suku sasak. Kaitannya seperti, makanan, kepercayaan dan perilaku ibu hamil pada umumnya.

Terkait dengan aspek budaya sasak yang berkaitan dengan kesehatan yang pertama adalah larangan mengkonsumsi gurita, cumi-cumi, kepiting, udang dan ikan pari. Ikan gurita dan cumi dianggap mempunyai kaki yang lekat dan mencengkeram, hal ini dapat menyebabkan tertahannya ari-ari bayi akan melekat dan mencengkeram di rahim ibu sehingga bayi susah lahir. Makan udang yang bentuknya melengkung dianggap akan menyebabkan bayi berbentuk serupa sehingga mempersulit kelahiran. Ikan pari yang hidungnya tajam akan menyebabkan bayi sulit keluar, sementara kepiting menyebabkan bayi akan lebih dahulu keluar tangannya atau letaknya melintang.

Gizi kurang pada ibu hamil dapat menyebabkan resiko dan komplikasi pada ibu antara lain : anemia, kurang energi kronis (KEK), pendarahan, berat badan ibu tidak bertambah secara normal, dan terkena penyakit infeksi. Pengaruh gizi kurang terhadap proses persalinan dapat mengakibatkan persalinan sulit dan lama, persalinan sebelum waktunya (premature), pendarahan setelah persalinan, serta persalinan dengan operasi cenderung meningkat. Kekurangan gizi pada ibu hamil juga dapat mempengaruhi proses pertumbuhan janin dan dapat menimbulkan keguguran, abortus, bayi lahir mati, kematian neonatal, cacat bawaan, anemia pada bayi, asfiksia intra partum (mati dalam kandungan), lahir dengan berat badan lahir rendah (BBLR) (Kristiyanasari, 2010).

Angka kejadian ibu hamil penderita anemia dan kurang energi protein masih tinggi. Frekuensi ibu hamil dengan anemia di Indonesia relatif tinggi, yaitu 63,5\%. Berdasarkan laporan dari provinsi tahun 2009, pemberian tablet tambah darah (Fe3) pada ibu hamil telah mencakup 68,5\%, beberapa provinsi seperti provinsi Bali, Lampung dan NTB, mempunyai cakupan di atas $80 \%$, sedangkan provinsi Sulawesi Tengah, Papua Barat, dan Papua di bawah $40 \%$. Penanggulangan masalah anemia gizi besi saat ini terfokus pada pemberian tablet tambah darah $(\mathrm{Fe})$ yaitu 90 tablet selama kehamilan (UNICEF, 2009)

Prevalensi resiko KEK pada wanita usia subur (WUS) di Indonesia sebesar 19,1\%. Terdapat keragaman prevelansi resiko KEK menurut provinsi, diantaranya yang termasuk kategori berat ditemukan di NTT (40,8\%), katagori sedang di lima provinsi yaitu NTB (26,7\%), Papua (25,7\%), Bangka Belitung (22,4\%), Jawa Tengah $(22,2 \%)$ dan Jawa Timur (21,9\%). Revalensi risiko KEK pada WUS di Kawasan Timur Indonesia adalah tertinggi dibandingkan Sumatera dan Jawa Bali. Berdasarkan daerah desa dan kota menunjukkan prevalensi risiko KEK pada WUS di perdesaan (21.1\%) lebih tinggi dari pada di perkotaan $(17.3 \%)$ (Riskesdas 2013). 
Berdasarkan data yang didapat oleh peneliti jumlah ibu hamil di wilayah Kerja Puskesmas Parampuan Labuapi tahun 2015 pada periode juli sebanyak 393 orang, sedangkan ibu hamil yang mengalami (KEK) berjumlah 8 orang, dan tidak ada mengalami anemia.

Pengetahuan ibu terhadap gizi dan permasalahannya sangat berpengaruh terhadap status gizi keluarga. Ibu hamil yang memiliki pengetahuan gizi yang baik akan mampu memilih jenis makanan yang tepat untuk dirinya dan janinnya baik dari segi kuantitas maupun kualitas.

Faktor yang berpengaruh terhadap tingginya angka kamatian ibu adalah pengetahuan ibu terhadap gizi. Beberapa faktor yang melatar belakangi resiko kematian ibu tersebut adalah kurangnya partisipasi masyarakat yang disebabkan tingkat pendidikan ibu rendah, kemampuan ekonomi keluarga rendah, kedudukan sosial budaya yang tidak mendukung. Jika ditarik lebih jauh beberapa perilaku tidak mendukung tersebut juga bisa membawa resiko (Elverawati, 2008).

Apabila seorang ibu hamil memiliki pengetahuan yang lebih tentang resiko tinggi kehamilan maka kemungkinan besar ibu akan berpikir untuk menentukan sikap, berperilaku untuk mencegah, menghindari atau mengatasi masalah resiko kehamilan tersebut.

Berdasarkan uraian latar belakang di atas, peneliti tertarik untuk meneliti tentang Pengaruh Budaya Sasak dan Pengetahuan Ibu terhadap status Gizi Ibu Hamil di Wilayah Kerja Puskesmas Labuapi Kabupaten Lombok Barat, Propinsi NTB.

\section{METODE PENELITIAN}

$\begin{array}{lcr}\text { Penelitian } & \text { ini } & \text { merupakan } \\ \text { penelitian } & \text { kuantitatif } & \text { dengan }\end{array}$

menggunakan desain Correlational dengan pendekatan crossectional yaitu variabel sebab atau risiko dan akibat atau kasus yang terjadi pada objek penelitian diukur dan dikumpulkan secara simultan dan bersamaan.

Penelitian ini bertujuan untuk mengetahui Pengaruh Budaya Sasak dan Pengetahuan Ibu terhadap Status Gizi Ibu Hamil. Data diambil melalui metode Wawancara dengan menggunakan Pedoman Wawancara untuk mengkaji budaya Sasak dan Kuesioner untuk mengukur pengetahuan. Sedangkan untuk mendapatkan Status Gizi Ibu Hamil mengisi lembar observasi yang dilakukan dengan Pengukuran LILA pada ibu Hamil.

Teknik penentuan sampel yang digunakan adalah quota sampling adalah pengambilan sampel secara quota dilakukan dengan cara menetapkan sejumlah anggota sampel secara quotum atau jatah sejumlah 30 responden.

Tahap pelaksanaan dimulai Memberikan penjelasan pada semua subjek penelitian dan kesediaannya menjadi sampel dalam penelitian dengan persetujuan dalam informed consent. Kemudian masing-masing responden dilakukan wawancara terkait budaya Sasak dan mengisi lembar kuesioner untuk mengukur tingkat pengetahuan. Setelahnya, baru dilakukan pengukuran LILA pada Ibu Hamil. Analisa data dalam penelitian ini yaitu menggunakan uji Chi Square.

\section{HASIL PENELITIAN}

Penelitian ini dilakukan kepada 30 Ibu Hamil yang ditetapkan sebagai sampel di Wilayah Kerja Puskesmas Parampuan Kecamatan Labuapi yang terdiri dari 6 desa yaitu Desa Parampuan, Karang Bongkot, Kuranji, Kuranji Dalang, Bajur, Karang Tawah. 
Data umum menyajikan karakteristik distribusi responden

a. Karakteristik responden berdasarkan umur

Berikut ini diuraikan karakteristik secara terperinci mengenai penyebaran responden berdasarkan kelompok umur resiko kehamilan.

Tabel 4.1 Distribusi Responden Berdasarkan Umur

\begin{tabular}{|c|c|c|c|}
\hline \multirow{2}{*}{ No } & \multirow{2}{*}{ Umur } & \multicolumn{2}{|c|}{ Frekuensi } \\
\cline { 3 - 4 } & & $\mathrm{N}$ & $\%$ \\
\hline 1 & $<20$ tahun & 3 & 10.0 \\
\hline 2 & $20-35$ tahun & 26 & 86.7 \\
\hline 3 & $>35$ tahun & 1 & 3.3 \\
\hline \multicolumn{2}{|c}{ Jumlah } & 30 & 100.0 \\
\hline
\end{tabular}

Berdasarkan tabel 4.1 di atas,dari 30 responden, sebagian besar pada kelompok umur kurang beresiko (2035 tahun), yaitu sebanyak 26 responden (86\%).

b. Karakteristik responden berdasarkan Paritas

Tabel 4.2 Distribusi Responden Berdasarkan Paritas

\begin{tabular}{|c|c|c|c|}
\hline No & Paritas & $\mathrm{N}$ & $\%$ \\
\hline 1. & Primigravida & 8 & 26,7 \\
\hline 2. & Multigravida & 22 & 73,3 \\
\hline 3. & Grandemultigravida & 0 & 0 \\
\hline \multicolumn{2}{|r|}{ Total } & 30 & 100 \\
\hline
\end{tabular}

Berdasarkan tabel menunjukkan bahwa distribusi responden terbanyak adalah yang multigravida sebanyak 22 responden $(73,3 \%)$ dan tidak ada responden grandemultigravida.

c. Karakteristik responden berdasarkan Pendidikan

\begin{tabular}{|c|c|c|c|}
\hline No & Sikap terhadap budaya sasak & $\mathrm{N}$ & $(\%)$ \\
\hline 1 & $\begin{array}{l}\text { Mendukung budaya yang } \\
\text { mendukung gizi }\end{array}$ & 0 & 0.0 \\
\hline 2 & $\begin{array}{l}\text { Mendukung budaya yang } \\
\text { tidak mendukung gizi }\end{array}$ & 9 & 30.0 \\
\hline 3 & $\begin{array}{l}\text { Mendukung budaya yang } \\
\text { tidak berhubungan dengan } \\
\text { gizi atau tidak memegang } \\
\text { budaya sasak }\end{array}$ & 21 & 70.0 \\
\hline & Total & 30 & 100 \\
\hline
\end{tabular}

Tabel 4.3 Distribusi Responden Berdasarkan Pendidikan

\begin{tabular}{|c|l|c|c|}
\hline No & Tingkat Pendidikan & N & $(\%)$ \\
\hline 1 & Tidak tamat SD & 3 & 10.0 \\
\hline 2 & SD & 12 & 40.0 \\
\hline 3 & SMP & 7 & 23.3 \\
\hline 4 & SMA & 4 & 13.3 \\
\hline 5 & PT Total & 3 & 10 \\
\hline \multicolumn{2}{|c|}{ Tol } & 30 & 100 \\
\hline
\end{tabular}

Sumber : Data primer yang diolah

Berdasarkan table 4.5 di atas, dari

30 responden menunjukkan bahwa distribusi terbanyak adalah yang berpendidikan SD sebanyak 12 responden (40\%) dan terendah sebanyak $3(10 \%)$ responden yang tidak sekolah dan PT.

d. Karakteristik responden berdasarkan usia kehamilan

Tabel 4.4 Distribusi Responden Berdasarkanan usia kehamilan (Trimester)

\begin{tabular}{|c|c|c|c|}
\hline No & Usia Kehamilan & $\mathrm{N}$ & $\%$ \\
\hline 1 & Trimester 2 & 10 & 33.3 \\
\hline 2 & Trimester 3 & 20 & 66.7 \\
\hline \multicolumn{2}{|r|}{ Total } & 30 & 100 \\
\hline
\end{tabular}

Berdasarkan tabel 4.4 di atas terlihat bahwa dari 30 responden, sebagian besar responden usia kehamilannya berada pada trimester 3, yaitu sebanyak 20 responden $(66,7 \%)$.

Data khusus ini menyajikan hasil yang menggambarkan tentang Budaya Sasak, Pengetahuan Ibu dan Nutrisi Ibu hamil di Wilayah Kerja Puskesmas Labuapi, Lombok Barat

a. Budaya Sasak di Wilayah Kerja Puskesmas Parampuan labuapi.

Tabel 4.7 Distribusi berdasarkan sikap responden terhadap budaya mendukung dan tidak mendukung konsep gizi.

Sumber : data yang diolah

Berdasarkan tabel 4.6 di atas, bahwa dari 30 responden terbanyak adalah budaya yang tidak berhubungan dengan gizi atau tidak yang memegang budaya sasak sebanyak 21 responden (70\%) dan tidak ada responden yang budaya mendukung gizi. 
b. Pengetahuan ibu hamil terhadap status gizi di wilayah Kerja Puskesmas Parampuan Labuapi Tabel 4.8 Distribusi responden berdasarkan pengetahuan ibu hamil tentang gizi di wilayah Kerja Puskesmas Parampaun Labuapi.

\begin{tabular}{|c|c|c|c|}
\hline No & Pengetahuan & Frekuensi & $\begin{array}{c}\text { Persentase } \\
(\%)\end{array}$ \\
\hline 1 & Baik & 0 & 0.0 \\
\hline 2 & Cukup & 7 & 23.3 \\
\hline 3 & Kurang & 23 & 76.7 \\
\hline & Total & 30 & 100 \\
\hline
\end{tabular}

Berdasarkan tabel 4.8 di atas, menunjukan bahwa dari 30 responden, sebagian besar dari responden pengetahuan kurang sebanyak $23(76.7 \%)$.

c. Status gizi ibu hamil di wilayah Kerja Puskesmas Parampuan Labuapi.

Tabel 4.9 Distribusi responden Berdasarkan status gizi ibu hamil di wilayah Kerja Puskesmas Parampuan Labuapi.

\begin{tabular}{|c|c|c|c|}
\hline No & Statu Gizi & Frekuensi & $\begin{array}{c}\text { Persentase } \\
(\%)\end{array}$ \\
\hline 1 & KEK & 2 & 6.7 \\
\hline 2 & Tidak KEK & 28 & 93.3 \\
\hline & Total & 30 & 100 \\
\hline
\end{tabular}

Berdasarkan tabel 4.9 di atas terlihat bahwa dari 30 responden, didapatkan status gizi dengan kekurangan energi kronik (KEK) sebanyak 2 responden $(6.7 \%)$, dan yang tidak KEK sebanyak 28 responden $(93.3 \%)$.

d. Menganalisa pengaruh budaya sasak terhadap status gizi ibu hamil di wilayah Kerja Puskesmas Parampuan Labuapi.

Berdasarkan hasil uji statistik Chi Square pengaruh budaya sasak dan pengetahuan ibu dengan status gizi ibu hamil di wilayah Kerja Puskesmas Parampuan Labuapi dengan menggunakan program SPSS versi 20,0 didapatkan hasil p.value sebesar $0.523 \quad(\mathrm{p}<0.05)$ oleh karena itu dapat disimpulkan
$\mathrm{H}_{0} 1$ diterima dan Ha1 ditolak, yang artinya tidak ada pengaruh budaya sasak terhadap status gizi ibu hamil suku sasak di wilayah Kerja Puskesmas Parampuan Labuapi.

e. Menganalisa pengetahuan ibu hamil terhadap status gizi di wilayah kerja Puskesmas Parampuan Labuapi.

Berdasarkan hasil uji statistik chi square pengaruh budaya sasak dan pengetahuan ibu hamil dengan status gizi ibu hamil di wilayah Kerja Puskesmas Labuapi dengan menggunakan program SPSS versi 20,0 didapatkan $\rho$-value $0.419>\alpha$ 0,05 oleh karena itu dapat disimpulkan $\mathrm{Ho} 2$ diterima dan $\mathrm{Ha} 2$ ditolak, maka tidak ada pengaruh pengetahuan ibu hamil terhadap gizi di wilayah Kerja Puskesmas Parampuan Labuapi.

\section{PEMBAHASAN}

Dari hasil penelitian di atas akan dibahas hasil penelitian sesuai dengan penelitian yang telah dilakukan.

1. Peranan budaya terhadap status gizi pada ibu hamil di wilayah Kerja Puskesmas Parampuan Labuapi Lombok Barat.

Berdasarkan tabel 4.6 di atas, bahwa dari 30 responden dengan budaya yang tidak mendukung gizi sebanyak 9 responden $(30.0 \%)$ dan budaya tidak berhubungan dengan gizi atau tidak memegang budaya sasak sebanyak 21 responden (70.0\%).

Dari hasil sebaran jawaban kuesioner kepada responden mengenai budaya di wilayah Kerja Puskesmas Parampuan Labuapi, bahwa dari 30 responden yang didapatkan sebagian besar budaya tidak berhubungan dengan gizi atau 
tidak memegang budaya sasak yaitu sebanyak 21 orang.

Hasil penelitian ini berbeda dengan penelitian yang dilakukan oleh Aisyah Susanti (2013) yang mengemukakan status gizi pada ibu hamil trimester III sebagian besar termasuk kategori baik yang terdapat hubungan antar budaya pantangan dengan gizi ibu hamil. Perbedaan dari hasil penelitian ini didapatkan hasil p.value sebesar 0,523 $(p<0,05)$, oleh karena itu dapat disimpulakan Ho1 diterima dan Ha1 ditolak, yang artinya tidak ada pengaruh budaya tehadap status gizi ibu hamil di wilayah Kerja Puskesmas Parampuan Labuapi, karenakan di Suku Sasak sudah banyak responden yang tidak memegang budaya atau mendukung budaya yang tidak berhubungan dengan gizi hal ini disebabkan sebagian besar responden mengetahui budaya tetapi tidak melakukannya atau diterapkan oleh responden dalam kehidupannya.

Budaya memberi peranan dan nilai yang berbeda terhadap pangan dan makanan. Pada makanan yang masih dijumpai di beberapa daerah. Makanan yng merupakan bagian dari budaya menganggap makananmakanan tertentu dan berbahaya karena alasan-alasan yang tidak logis. Hal ini mengindikasikan masih rendahnya pemahaman gizi masyarakat dan oleh sebab itu perlu berbagai upaya tenaga kesehatan untuk memperbaikinya. Pantangan adalah suatu larangan untuk mengkomsumsi suatu jenis makanan tertentu dapat mengancam bahaya atau hukuman yang melanggarnya.

Di Suku Sasak masih ada yang percaya bahwa dengan mengkomsumsi makanan yang berasal dari sumber hewani (gurita, cumi-cumi, kepiting, udang dan ikan pari) akan menyebabkan saat persalinan janin susah keluar dan kepala janin keluar masuk, dan jika mengkomsumsi gurita dan cumi-cumi akan menyebabkan ari-arinya melekat pada rahim ibu. Selain itu, unsurunsur budaya mampu menciptakan suatu kebiasan makan masyarakat yang kadang bertentangan dengan prinsip-prinsip gizi. Permasalahan gizi pada ibu hamil tidak terlepas dari faktor budaya setempat. Kepercayaan bahwa ibu hamil dan post partum pantangan mengkomsumsi makanan tertentu menyebabkan kondisi ibu post partum kehilangan zat gizi yang berkualitas (Ratnawati, 2005).

Oleh kerena itu, penyuluhan gizi penting untuk terus menerus dilakukan untuk memperbaiki pengetahuan gizi dan kebiasaan masyarakat. Penyuluhan gizi menjadi landasan terjadinya perubahan pengetahuan. Sikap dan ketrampilan kelembagaan gizi seperti posyandu perlu lebih diperkuat sehigga aktivitas penyuluhan tidak terabaikan.

2. Pengetahuan ibu hamil terhadap status gizi di wilayah Kerja Puskesmas Parampuan Labuapi.

Berdasarkan tabel 4.7 di atas, menunjukkan bahwa dari 30 responden, terdapat 23 responden $(76.7 \%)$ berada pada kategori pengetahuan kurang, 7 responden $(23.3 \%)$ berada pada kategori pengetahuan cukup, dan tidak terdapat pengetahuan baik.

Dari hasil sebaran jawaban kuesioner kepada responden mengenai pengetahuan ibu tentang status gizi di wilayah Kerja Puskesmas Puskesmas Labuapi Lombok barat, sebagian besar berpengetahuan ibu kurang 21 responden, 7 responden pada kategori cukup, dan tidak ada responden kategori baik. Hal ini disebabkan 
karena sebagai bukti dari hasil pengisian jawaban kuesioner tidak mengetahui manfaat, kandungan, dampak dari kekurangan mengkonsumsi jenis makanan yang dibutuhkan ibu hamil, Hasil itu didukung karena sebagian besar responden berpendidikan SD, SMP, SMA dan perguruan tinggi.

Hasil penelitian ini berbeda dengan penelitian yang pernah dilakukan oleh RAJ. Budiani Retnaningsih (2010), tentang pengetahuan ibu hamil tentang gizi dengan status gizi ibu hamil trimester III, yang mengungkapkan bahwa pengetahuan mempengaruhi status gizi pada ibu hamil trimester III. Sedangkan dari hasil penelitian ini didapatkan hasil p-value 0.419 $(p<0,05)$ oleh karena itu, dapat disimpulkan $\mathrm{Ho} 2$ diterima dan $\mathrm{Ha} 2$ ditolak, maka tidak ada pengaruh pengetahuan ibu hamil terhadap status gizi di wilayah Kerja Puskesmas Parampuan Labuapi.

$$
\text { Adanya pengaruh yang }
$$

berpengetahuan kurang namun mempunyai gizi yang lebih, dikarenakan mungkin responden mempunyai daya beli tinggi terhadap makanan gizi tinggi meskipun pengetahuanya kurang. Menurut Notoatmodjo (2007), menyatakan perilaku dipengaruhi kepercayaan atau persepsi variabel sosial, demografis, pengetahuan, kebudayaan, ancaman, manfaat dan terdapatnya faktor pencetus isyarat untuk bertindak. Dimana pengetahuan merupaka perlu tetapi belum tentu cukup untuk terjadinya perubahan prilaku.

Pengetahuan tentang kandungan gizi dalam berbagai bahan makanan, kegunaan makanan bagi kesehatan kelurga dapat membantu ibu memilih bahan makanan yang harganya tidak begitu mahal akan tetapi nilai gizinya tinggi. Memiliki pengetahuan gizi tidak berati seseorang mau mengubah kebiasaan makananya. Seseorang mungkin paham tentang protein, karbohidrat, vitamin dan gizi lainya yang diperlukan untuk keseimbangan diit tetapi tidak pernah mengaplikasikan pengetahuan gizi ini kedalam kehidupan sehari-hari.

\section{Status gizi ibu hamil di Wilayah kerja Puskesmas Parampuan Labuapi.}

Berdasarkan tabel 4.9 dari hasil penelitian menunjukkan bahwa dari 30 responden, sebagian besar status gizi ibu hamil berdasarkan indikator LILA pada kategori yang tidak memiliki kekurangan energi kronik (KEK) sebanyak 28 responden (93.3\%), dan pada kategori mengalami kekurangan energi kronik (KEK) sebanyak 2 responden $(6.7 \%)$

Dari hasil observasi yang dilakukan oleh peneliti pada 30 responden sebagian besar status gizi ibu hamil yakni pada kategori tidak KEK yaitu sebanyak 28 responden.

Hasil penelitian yang dilakukan pada ibu hamil di wilayah Kerja Puskesmas Parampuan, faktor yang mempengaruhi status gizi dari segi umur, paritas, pendidikan yang dapat mempengaruhi terjadinya KEK pada ibu hamil.

Dari segi umur, 6,7\% ternyata responden yang mengalami KEK berada pada kelompok umur kurang beresiko (20-35 tahun) dengan 2 reponden mengalami KEK. Dari segi pendidikan, $6,7 \%$ responden yang KEK memiliki tingkat pendidikan SMP dan SMA. Dari segi paritas, $6,7 \%$ responden yang mengalami KEK pada Primigravida dan Multigravida.

Dari 3 faktor tersebut, yang lebih dominan yang mempengaruhi 
terjadinya KEK pada ibu hamil di wilayah Kerja Puskesmas Parampuan Labuapi adalah faktor budaya dan pengetahuan.

Berdasarkan hasil penelitian sebagian responden sudah tidak memegang budaya atau mendukung budaya yang tidak berhubungan dengan gizi, sedangkan hasil penelitian pengetahuan masih banyak responden memiliki pengetahuan kurang tentang pemberian gizi, mungkin kurangnya kesadaran untuk lebih meningkatkan pengetahuan. Dalam hal ini, dikarenakan yang kurang dari lingkungan yang tidak mendidik kearah tertentu.

Disamping itu status gizi sangat penting diketahui ibu hamil karena akan berpengaruh pada pertumbuhan janin yang dikandung. Status gizi ibu hamil sangat mempengaruhi pertumbuhan janin yang sedang dikandung. Bila status gizi ibu normal pada masa kehamilan maka kemungkinan membebesarkan melahirkan bayi yang sehat, cukup bulan dengan berat badan normal. Dengan kata lain kualitas bayi yang dilahirkan sangat tergantung pada keadaan gizi ibu hamil (Lubis, 2003).

\section{KESIMPULAN}

Berdasarkan hasil penelitian dan pembahasan pada Bab sebelumnya, maka dapat ditarik kesimpulan sebagai berikut:

1. Berdasarkan peranan budaya Sasak terhadap status gizi pada ibu hamil di wilayah Kerja Puskesmas Parampuan Labuapi terdapat 30 responden terkait dengan budaya sasak terlihat bahwa dari 30 responden dengan mendukung budaya yang mendukung gizi atau tidak memegang budaya sasak sebanyak 21 responden $(70.0 \%)$.
2. Berdasarkan pengetahuan ibu hamil terhadap status gizi di wilayah Kerja Puskesmas Parampuan Labuapi menunjukan bahwa dari 30 responden yang terbanyak dengan pengetahuan kurang sebanyak 23 (76.7\%) sehingga pendidikan responden mempengaruhi pengetahuan tentang gizi pada ibu hamil.

3. Berdasarkan status gizi ibu hamil di wilayah Kerja Puskesmas Parampuan Labuapi menunjukkan bahwa dari 30 responden sebagian besar status gizi ibu hamil berdasarkan indikator LILA pada kategori yang tidak memiliki kekurangan energi kronik (tidak KEK) sebanyak 28 responden $(93.3 \%)$, dan pada kategori yang mengalami kekurangan energi kronik (KEK) sebanyak 2 responden (6.7\%).

4. Analisa pengaruh budaya sasak terhadap status gizi ibu hamil, hasil uji statistik Chi Square pengaruh budaya sasak terhadap status gizi ibu hamil di wilayah Kerja Puskesmas Parampuan Labuapi dengan menggunakan program SPSS versi 20,0 didapatkan hasil p.value sebesar 0.523 karena taraf signifikans $\alpha<0.05$ Maka dapat disimpulkan Ho di terima dan Ha ditolak yang artinya tidak ada pengaruh budaya terhadap status gizi ibu hamil suku di wilayah Kerja Puskesmas Parampuan Labuapi.

5. Analisa pengaruh pengetahuan ibu hamil terhadap gizi, hasil uji $C h i$ Square yang dilakukan didapatkan nilai $p=0.419$ dan taraf kesalahan 0,05 hal ini berarti $\mathrm{Ho} 2$ diterima dan $\mathrm{Ha} 2$ ditolak maka tidak ada pengaruh pengetahuan ibu hamil terhadap gizi di wilayah Kerja Puskesmas Parampuan Labuapi.

\section{SARAN}

Mengingat pentingnya status gizi ibu hamil pihak puskesmas perlu 
memperhatikan nutrisi untuk ibu hamil dan tradisi budaya yang ada di wilayah Kerja Puskesmas Parampuan Labuapi yang membahayakan bagi kesehatan ibu hamil dan janinya.

\section{DAFTAR PUSTAKA}

Arikunto, S. 2006. Prosedur Penelitian Suatu Pendekatan Praktek, Rineka Cipta: Jakarta.

Arisman, M.B.2007. buku Ajar Ilmu Gizi: Gizi dalam daur Kehidupan. Jakarta: EGC.

Depkes RI, 2004. Asuhan Persalinan Normal. Depkes RI. Jakarta

Depkes, 2009. Profil Kesehatan Indonesia 2008. Jakarta: di akses 18 mei 2011

Depkes RI. 2011. Target MDGs 2015. www.scribd.com/doc/49323435

/depkes-RIdiakses tanggal 11 September 2013.

Elverawati, 2008. Penurunan Angka kematian www.antranews.com diakses tanggal 20 febuari 2011

Hanim, 2005. Buku Ajar Konsep Kebidanan: Kehamilan. Yogyakarta: CV Andi OF SET.

Henny Gustini, Alfan. 2013. Studi Budaya di Indonesia. Bandung: CV Pustaka Lansia.

Heri, 2007. Anemia Pada Ibu Hamil www.kompas.com , diakses tanggal 10 januari 2011

Hidayat, 2009. Metodologi Penelitian Kesehatan. Jakarta: Bineka Cipta

Hidayat, Azis, Alimul. 2009. Riset Keperawatan dan Teknik Penulisan Ilmiah. Jakarta: Salemba Medika.

Kristyanasari, weni. 2010.Gizi Ibu Hamil. Nuha Medika. Jakarta

Lubis, 2007. Status Gizi Ibu Hamil Serta Pengaruhnya terhadap Bayi yang Dilahirkan http://tumoutou.net .

Mubarak Wahit Ikbal, 2009. Promosi Kesehatan. Jogjakarta: Graha Ilmu.
Nursalam. 2003. Konsep dan Penerapan Metodologi Penelitian Ilmu Keperawatan. Jakarta ; Salemba Medika.

Nursalam. 2008. Konsep dan Penerapan Metodologi Penelitian Ilmu Keperawatan. Jakarta : Salemba Medika.

Notoatmodjo, S. 2003. Metodelogi Penelitian Kesehatan. Jakarta: Rineka Cipta.

Paryanto, 1997. Ilmu Gizi,. Jakarta : EGC

Path. 2005. Gizi Dalam Kesehatan Reproduksi. Jakarta: EGC

Prasetyono, D.S. 2009. Buku Ajar Ilmu Gizi. Diva Press. Yogyakarta.

Ratnawati, 2005. Pengaruh Budaya dan Pengetahuan ibu www.academia.edu .

Riskesdas. 2013. Laporan Nasional Riset Kesehatan Dasar ( Riskesdas tahun 2013). Jakarta: Badan Penelitian dan Pengembangan Kesehatan Departemen Kesehatan RI

Rossyadi, 2001. Dasar Ilmu Budaya dan Pendidikan. Jakarta: Rineka Cipta

Sediaotama. 2000. Ilmu Gizi, PT. Dian Rakyat. Jakarta.

Stikes Mataram. 2013. Buku Panduan Skripsi. Mataram

Sugiyono. 2012. Statistika Untuk Penelitian. Bandung. Alfabeta. . 2009. Metode Penelitian Kuantitatif, Kualitatif. Bandung : Alfabeta.

Supariasa, etc. 2011. Penilaian Status Gizi. Jakarta. EGC. 2007. Buku Ajar Konsep

Kehamilan. Penerbit Buku Kedokteran, EGC : Jakarta.

Unicef Indonesia, 2009. Kesehatan Ibu dan Anak Ringkasan Kajian www.unicef.or.id febuari 2014

Walsh, L,V 2007. Buku Ajar Kebidanan Komunitas. Jakarta: EGC 